VOL. 7

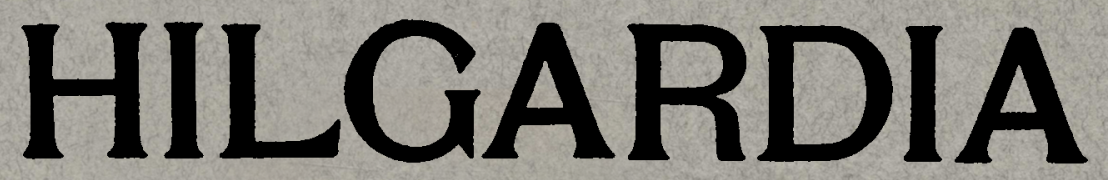

A Journal of Agricultural Science PUBLISHED BY THE

California Agricultural Experiment Station

\author{
CONTENTS
}

Deterrent Effect of Artificial Light on the Codling Moth

\author{
W. B. HERMS
}




\title{
HILGARDIA
}

\author{
A JOURNAL OF AGRICULTURAL SCIENCE \\ PUBLISHED BY THE
}

CALIFORNIA AGRICULTURAL EXPERIMENT STATION

VOL. 7

DECEMBER, 1932

No. 7

\section{DETERRENT EFFECT OF ARTIFICIAL LIGHT ON THE CODLING MOTH ${ }^{1,2}$}

W. B. HERMS 3

The results of a codling-moth light experiment conducted during the summer of 1928 showed that the percentage of worminess in apples from trees in an artificially lighted area was less than that of apples from trees in an unlighted area : it was, therefore, concluded that light has a tendency to deter the codling moth in its egg-laying habits. ${ }^{4}$ When fruit of the same variety was compared at the end of the test, it was found that 21.0 per cent of the apples on check trees outside the test plot were moth attacked, while only 14.5 per cent of the apples inside the test plot were so affected.

\section{CONDITIONS OF THE EXPERIMENT}

For the purpose of that experiment, six 500-watt lamps were used during the evening hours from about an hour before sunset to about an hour after sunset, an illumination time of about 2 hours, during the period from May 1 to June 30. The peak of the codling-moth flight occurs from about 20 minutes before sunset to about 20 minutes after, hence the hours chosen for artificial illumination. A block of 15 trees was used.

\footnotetext{
1 Received for publication July 2, 1932.

2 This article is a contribution of the Division of Entomology and Parasitology, and the California Committee on the Relation of Electricity to Agriculture. It is the eighth of a series planned to report the results of investigations conducted jointly by the Agricultural Experiment Station, College of Agriculture, and the California Committee on the Relation of Electricity to Agriculture. The Committee represents the agricultural and electrical industries in California that are working together, in cooperation with similar committees in other states, for the purpose of making available reliable information concerning the use of electricity on the farm.

3 Professor of Parasitology and Entomologist in the Experiment Station.

4 Herms, W. B. A field test of the effect of artificial light on the behavior of the codling moth, Carpocapsa pomonella (Linn.). Jour. Econ. Ent. 22(1):78-88. 1929.
} 


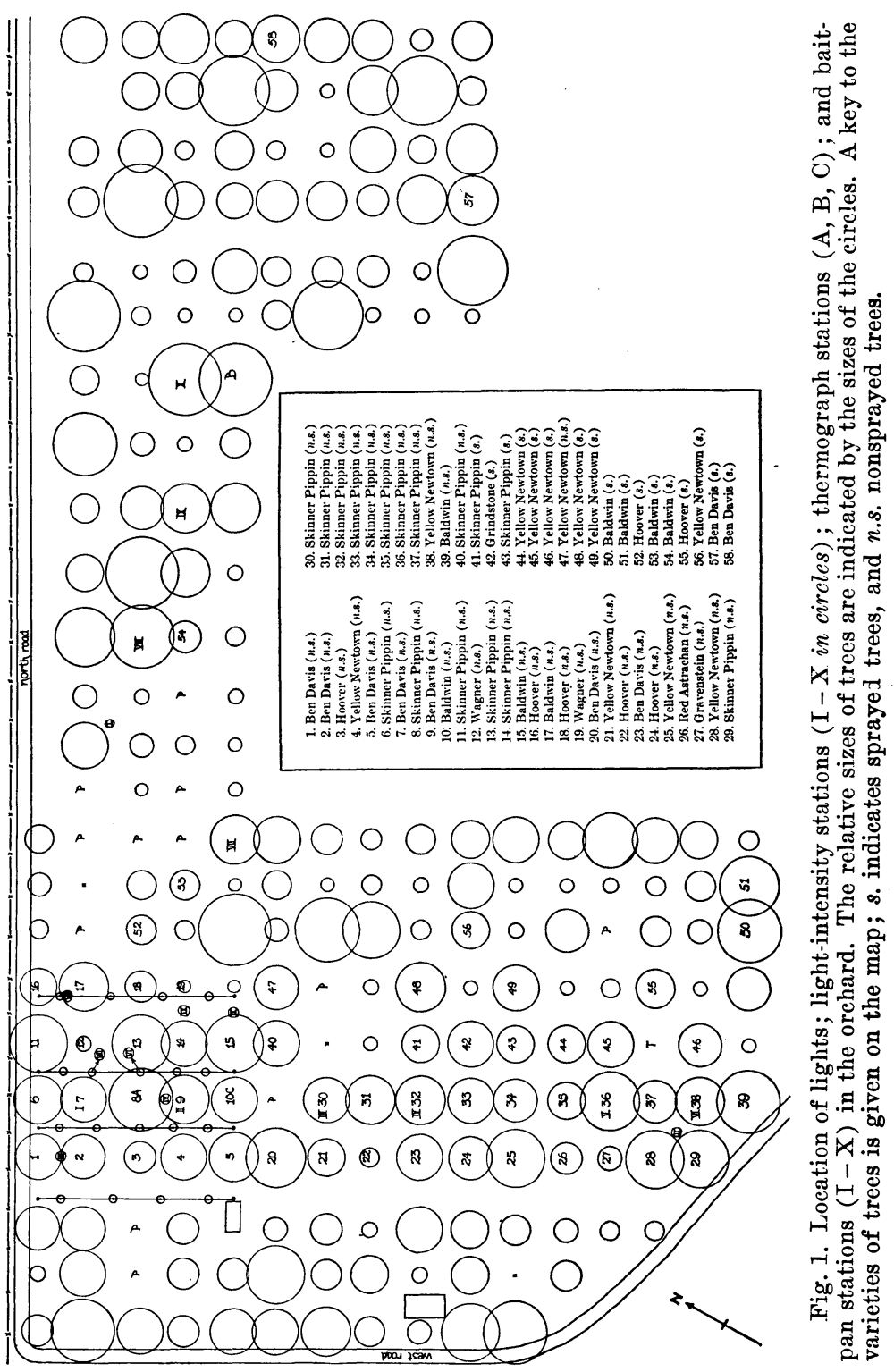


For the 1929 test the same plot of trees was used (fig. 1), but the number of 500-watt lamps was increased to eighteen and the period of illumination extended through the entire season, namely, from April 24 to October 24. During this entire time the lights were on every evening from 2 to 4 hours. All apples, including thinnings and windfalls, were examined for worminess. A total of 217,975 apples were examined from 51 trees, selected to permit comparison of fruit from illuminated and nonilluminated trees, and from sprayed and unsprayed trees.

The lamps (Mazda, 500-watt) were suspended over the tops of the trees from wires strung between poles as shown in figure 2. Twelve-inch white porcelain reflectors were used. The position of the lamps with reference to the tree tops depended, of course, upon the size of the trees.

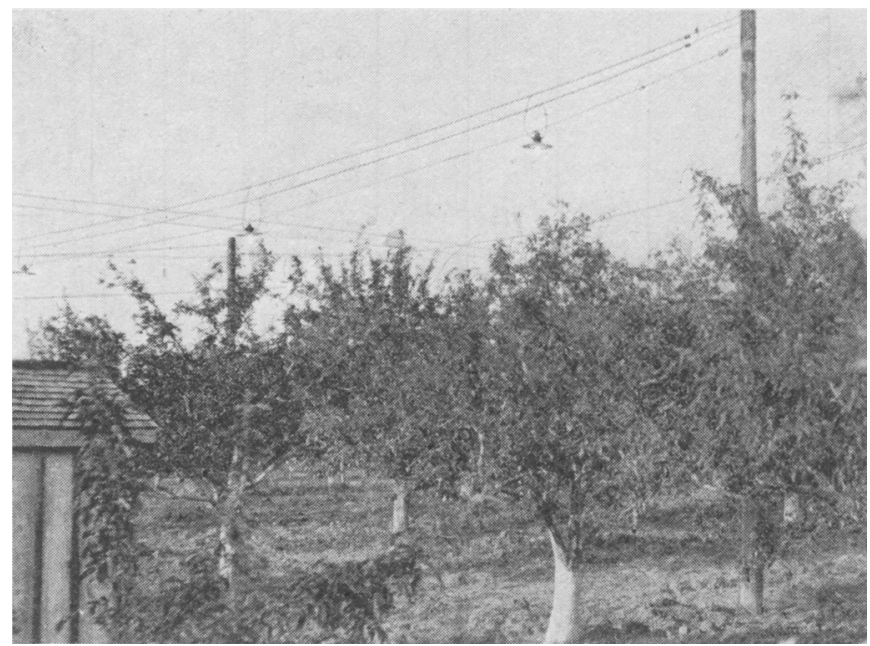

Fig. 2. Arrangement of lights suspended over the trees.

The light-intensity readings were taken by means of a MacBeth illuminometer. The automatic switch used for controlling the lights was a twopole, 115/230-volt Sauter time switch furnished with astronomic dial.

Ten stations were selected for light-intensity readings as shown in figure 1. Both temperature and humidity records were kept, as well as records on sunset time, weather conditions, and observed moth flights. Daily reports showing the above data were made in duplicate, and from this material a consolidated table was prepared. This consolidated table with supporting data is on deposit in the office of the California Agricultural Experiment Station at Berkeley, where it may be consulted by those interested. For the purpose of this report only an extract from the general table is here included to show characteristic data. (See table 1.) 
Table 1-Chimatic Data, Light-Intensity Readings and Bait-Pan Catches

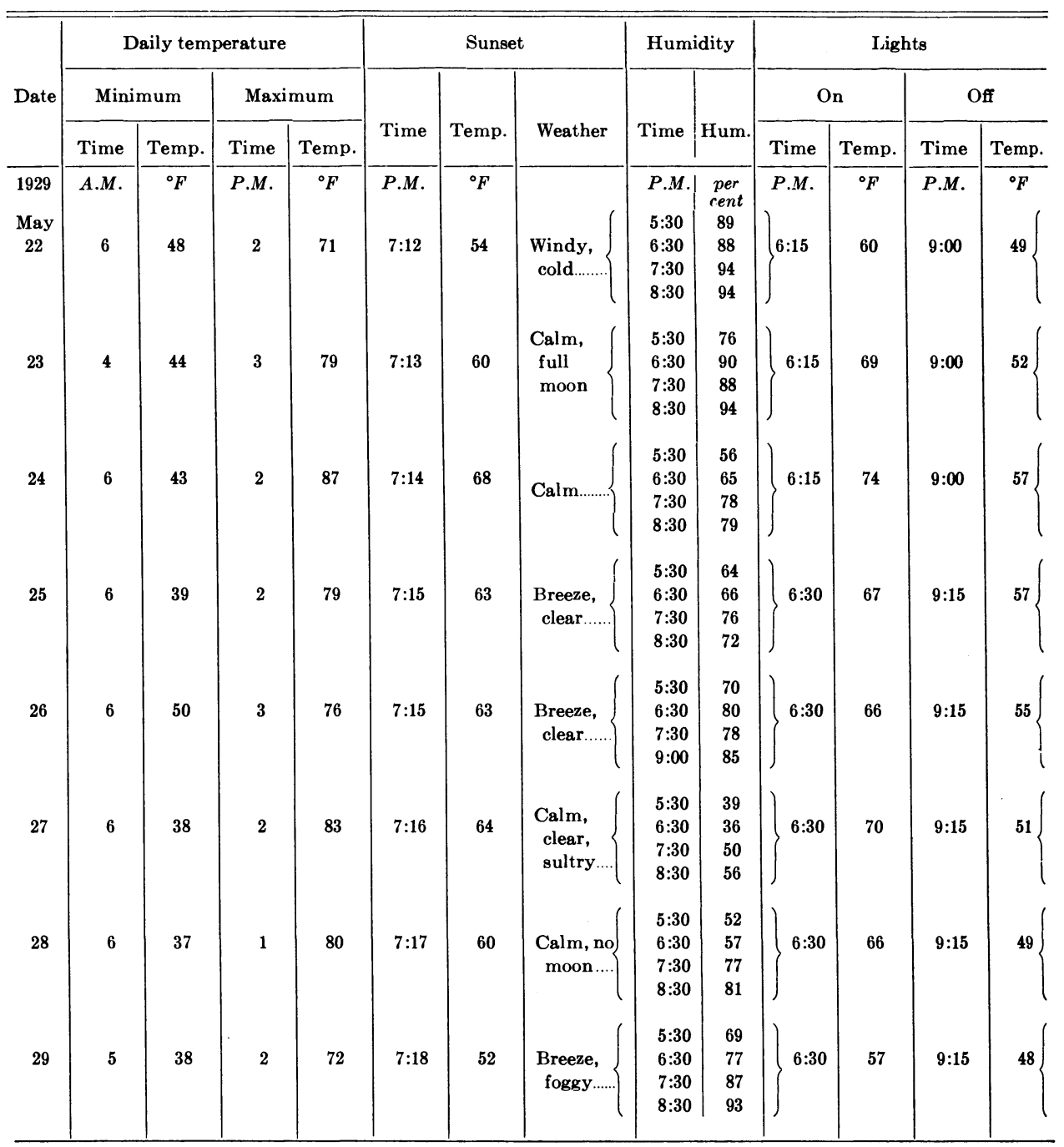


During the Two Peak Fligh'ts of the Codling Moth ; Sebastopol, California, 1929

\begin{tabular}{|c|c|c|c|c|c|c|c|c|c|c|c|c|c|c|c|c|}
\hline \multicolumn{6}{|c|}{ Light-intensity readings in foot-candles } & \multicolumn{11}{|c|}{ Number of moths in each bait trap } \\
\hline \multirow{2}{*}{ Time } & \multicolumn{3}{|c|}{ Stations outside lighted area } & \multicolumn{2}{|c|}{$\begin{array}{c}\text { Stations inside } \\
\text { lighted area }\end{array}$} & \multirow{2}{*}{$\begin{array}{c}\text { No. } \\
1\end{array}$} & \multirow{2}{*}{ No. } & \multirow{2}{*}{$\begin{array}{c}\text { No. } \\
3\end{array}$} & \multirow{2}{*}{$\begin{array}{c}\text { No. } \\
4\end{array}$} & \multirow{2}{*}{$\begin{array}{c}\text { No. } \\
5\end{array}$} & \multirow{2}{*}{ No. } & \multirow{2}{*}{ No. } & \multirow{2}{*}{$\begin{array}{c}\text { No. } \\
8\end{array}$} & \multirow{2}{*}{ No. } & \multirow{2}{*}{$\begin{array}{l}\text { No. } \\
10\end{array}$} & \multirow[t]{2}{*}{ Total } \\
\hline & No. 1 & No. 4 & No. 6 & No. 8 & No. 10 & & & & & & & & & & & \\
\hline P.M. & & & & & & & & & & & & & & & & \\
\hline $6: 30$ & ................. & 669.0 & 424.0 & 432.0 & 338.0 & & & & & & & & & & & \\
\hline $7: 00$ & $\ldots \ldots \ldots \ldots$ & 69.0 & 97.0 & 96.0 & 39.0 & 1 & 1 & 0 & 0 & 2 & 1 & 0 & 0 & 1 & 1 & 7 \\
\hline $7: 30$ & $\ldots \ldots \ldots \ldots$ & 6.5 & 38.0 & 33.0 & 2.6 & & & & & & & & & & & \\
\hline $8: 30$ & $\ldots \ldots \ldots \ldots$ & 5.4 & 33.0 & 31.0 & 2.4 & & & & & & & & & & & \\
\hline $6: 00$ & ․․․․…... & $1,574.0$ & 338.0 & $1,738.0$ & 3620 & & & & & & & & & & & \\
\hline 7:00 & ................. & 119.0 & 115.0 & 125.0 & 56.0 & 3 & 4 & 5 & 4 & 2 & 6 & 1 & 2 & 3 & 1 & 31 \\
\hline 8:00 & .................. & 5. 2 & 31.0 & 30.0 & 2.5 & & & & & & & & & & & \\
\hline $9: 00$ & $\ldots \ldots \ldots \ldots$ & 5.5 & 33.0 & 31.0 & 2.6 & & & . & & & & & & & & \\
\hline $6: 00$ & $\ldots$ & $1,574.0$ & 331.0 & $1,737.0$ & 362.0 & & & & & & & & & & & \\
\hline 7:00 & $\ldots \ldots \ldots \ldots$ & 74.0 & 113.0 & 121.0 & 55.0 & 17 & 17 & 7 & 12 & 19 & 11 & 5 & 10 & 14 & 15 & 127 \\
\hline $8: 00$ & $\ldots \ldots \ldots . .$. & 5.1 & 31.0 & 29.0 & 2.2 & & & & & & & & & & & \\
\hline 9:00 & $\ldots \ldots \ldots \ldots$ & 5.5 & 32.0 & 29.0 & 2.4 & & & & & & & & & & & \\
\hline $6: 00$ & .................. & $1,337.0$ & 456.0 & $1,495.0$ & 449.0 & & & & & & & & & & & \\
\hline 7:00 & $\ldots \ldots \ldots . .$. & 110.0 & 120.0 & 120.0 & 57.0 & 8 & 13 & 8 & 18 & 12 & 12 & 2 & 3 & 16 & 5 & 97 \\
\hline $8: 00$ & $\ldots \ldots \ldots . .$. & 4.3 & 30.6 & 23.2 & 2.2 & & & & & & & & & & & \\
\hline $9: 00$ & ................. & 5.5 & 32.4 & 27.8 & 2.5 & & & & & & & & & & & \\
\hline $6: 30$ & .................. & 125.0 & 167.0 & 213.0 & 189.0 & & & & & & & & & & & \\
\hline $7: 30$ & .................. & 6.4 & 9.0 & 31.0 & 14.0 & 6 & 13 & 13 & 12 & 11 & 20 & 13 & 13 & 27 & 10 & 138 \\
\hline $8: 30$ & .................. & 4.4 & 29.7 & 26.9 & 2.4 & & & & & & & & & & & \\
\hline $9: 00$ & ................ & 5.0 & 31.5 & 29.7 & 2.6 & & & & & & & & & & & \\
\hline $6: 00$ & .................. & $1,456.0$ & 377.0 & $1,495.0$ & 401.0 & & & & & & & & & & & \\
\hline $7: 00$ & ................. & 102.0 & 138.0 & 142.0 & 79.6 & 7 & 18 & 12 & 13 & 12 & 14 & 12 & 18 & 18 & 15 & 139 \\
\hline $8: 00$ & ............... & 4.8 & 29.7 & 24.0 & 2.3 & & & & & & & & & & & \\
\hline 9:00 & $\ldots \ldots \ldots . .$. & 4.9 & 30.6 & 27.8 & 2.5 & & & & & & & & & & & \\
\hline $6: 00$ & .................. & $1,737.0$ & 315.0 & $1,574.0$ & 354.0 & & & & & & & & & & & \\
\hline $7: 00$ & .................. & 118.0 & 177.0 & 119.6 & 59.0 & 2 & 4 & 1 & 1 & 4 & 2 & 1 & 1 & 6 & 2 & 24 \\
\hline $8: 00$ & ................... & 4.4 & 29.6 & 25.9 & 2.5 & & & & & & & & & & & \\
\hline $9: 00$ & ….............. & 5.1 & 31.5 & 28.7 & 2.7 & & & & & & & & & & & \\
\hline $6: 00$ & $\ldots \ldots \ldots . .$. & $1,259.0$ & 362.0 & $1,385.0$ & 377.0 & & & & & & & & & & & \\
\hline $7: 00$ & ................... & 101.9 & 156.9 & .................. & 116.0 & 0 & 1 & 1 & 0 & 0 & 1 & 2 & 0 & 1 & 0 & 6 \\
\hline $8: 00$ & ................. & 5.2 & 30.6 & 29.6 & 2.4 & & & & & & & & & & & \\
\hline 9:00 & $\ldots \ldots \ldots . .$. & 5.3 & 33.7 & 31.5 & 2.5 & & & & & & & & & & & \\
\hline
\end{tabular}


TaBLE 1-Chimatic Data, Light-Intensity Readings and Bait-Pan Catches During

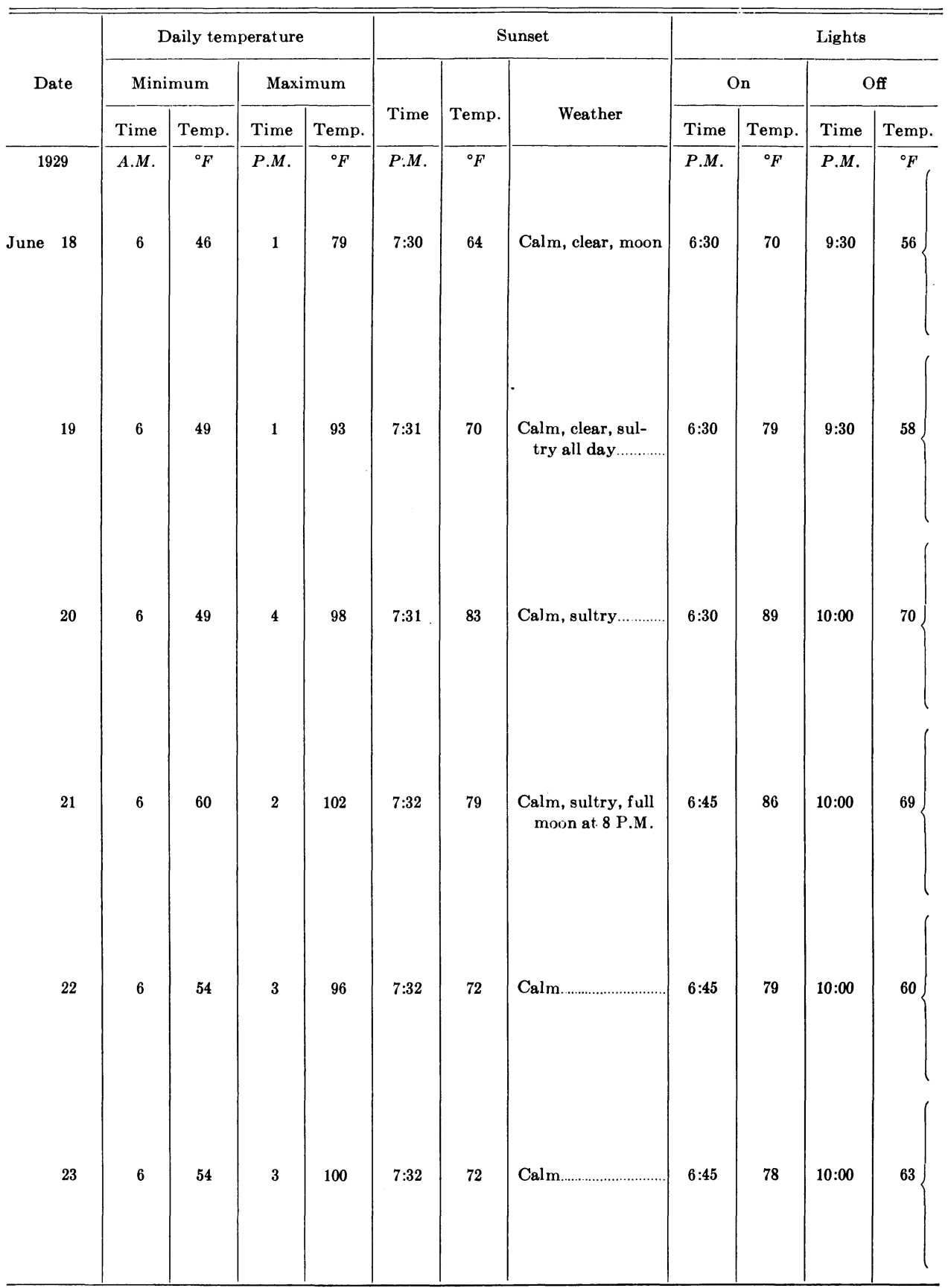


Dec., 1932] Herms: Effect of Artificial Light on Codling Moth

the Two Peak Flights of the Codling Moth; Sebastopol, California, 1929.-(Concluded)

\begin{tabular}{|c|c|c|c|c|c|c|c|c|c|c|c|c|c|c|c|c|}
\hline \multicolumn{6}{|c|}{ Light-intensity readings in foot-candles } & \multicolumn{11}{|c|}{ Number of moths in each bait trap } \\
\hline \multirow{2}{*}{ Time } & \multicolumn{3}{|c|}{ Stations outside lighted area } & \multicolumn{2}{|c|}{$\begin{array}{c}\text { Stations inside } \\
\text { lighted area }\end{array}$} & \multirow{2}{*}{$\begin{array}{c}\text { No. } \\
1\end{array} \mid$} & \multirow{2}{*}{ No. } & \multirow{2}{*}{$\begin{array}{c}\text { No. } \\
3\end{array}$} & \multirow{2}{*}{ No. } & \multirow{2}{*}{ No. } & \multirow{2}{*}{ No. } & \multirow{2}{*}{ No. } & \multirow{2}{*}{$\begin{array}{c}\text { No. } \\
8\end{array}$} & \multirow{2}{*}{$\begin{array}{c}\text { No. } \\
9\end{array}$} & \multirow{2}{*}{ No. } & Total \\
\hline & No. 1 & No. 4 & No. 6 & No. 7 & No. 10 & & & & & & & & & & & \\
\hline $6: 00$ & .................. & $1,416.0$ & ……....... & 708.0 & .. & & & & & & & & & & & \\
\hline ......... & 315.0 & 197.0 & 204.0 & 220.0 & 244.0 & & & & & & & & & & & \\
\hline $6: 30$ & 244.0 & 165.0 & 196.0 & 283.0 & 196.0 & & & & & & & & & & & \\
\hline $7: 00$ & 158.0 & 102.0 & 149.0 & 197.0 & 134.0 & & & & & & & & & & & \\
\hline $7: 30$ & 37.0 & 29.6 & 59.2 & 63.0 & 30.5 & 1 & 1 & 2 & 4 & 4 & 1 & 3 & 0 & 5 & 5 & 26 \\
\hline 8:00 & 0.84 & 4.2 & 21.3 & 19.4 & 3.0 & & & & & & & & & & & \\
\hline $8: 30$ & 0.01 & 3.3 & 20.4 & 18.5 & 2.3 & & & & & & & & & & & \\
\hline 9:00 & 0.0 & 3.7 & 21.3 & 19.4 & 2.5 & & & & & & & & & & & \\
\hline $6: 00$ & $\ldots \ldots .$. & $1,180.0$ & ................... & $1,101.0$ & $\ldots \ldots .$. & & & & & & & & & & & \\
\hline$\ldots \ldots .$. & 268.0 & 197.0 & 189.0 & 236.0 & 236.0 & & & & & & & & & & & \\
\hline $6: 30$ & 228.0 & 157.0 & 181.0 & 291.0 & 204.0 & & & & & & & & & & & \\
\hline 7:00 & 157.0 & 102.0 & 130.0 & 188.0 & 133.0 & 2 & 0 & 2 & 0 & 3 & 3 & 1 & 2 & 3 & 6 & 22 \\
\hline $7: 30$ & 40.7 & 27.7 & 50.9 & 60.2 & 33.3 & & & & & & & & & & & \\
\hline 8:00 & 0.28 & 3.6 & 19.4 & 17.6 & 2.1 & & & & & & & & & & & \\
\hline $8: 30$ & 0.0 & 3.0 & 17.6 & 15.7 & 1.9 & & & & & & & & & & & \\
\hline $9: 00$ & 0.0 & 3.3 & 18.0 & 16.0 & 2.1 & & & & & & & & & & & \\
\hline $6: 00$ & ……......... & $1,101.0$ & ................. & 787.0 & ................. & & & & & & & & & & & \\
\hline$\ldots \ldots . .$. & 268.0 & 197.0 & 197.0 & 236.0 & 236.0 & & & & & & & & & & & \\
\hline $6: 30$ & 228.0 & 149.0 & 189.0 & 291.0 & 197.0 & & & & & & & & & & & \\
\hline 7:00 & 140.0 & 88.0 & 111.0 & 166.0 & 125.0 & 2 & 4 & 2 & 4 & 9 & 6 & 6 & 3 & 9 & 11 & 56 \\
\hline $7: 30$ & 27.8 & 21.6 & 46.3 & 50.0 & 23.1 & & & & & & & & & & & \\
\hline $8: 00$ & 0.65 & 3.5 & 18.5 & 16.6 & 2.2 & & & & & & & & & & & \\
\hline $8: 30$ & 0.01 & 3.2 & 16.6 & 14.8 & 2.0 & & & & & & & & & & & \\
\hline $9: 00$ & 0.0 & 3.6 & 17.6 & 15.7 & 2.4 & & & & & & & & & & & \\
\hline $6: 00$ & & & ………. & $1,180.0$ & ……..... & & & & & & & & & & & \\
\hline ......... & 295.0 & 196.0 & 188.0 & 236.0 & 228.0 & & & & & & & & & & & \\
\hline $6: 30$ & 228.0 & 149.0 & 181.0 & 291.0 & 196.0 & & & & & & & & & & & \\
\hline $7: 00$ & 149.0 & 87.0 & 111.0 & 157.0 & 125.0 & 7 & 4 & 8 & 3 & 13 & 10 & 6 & 10 & 7 & 30 & 98 \\
\hline $7: 30$ & 3.7 & 25.0 & 48.0 & 58.0 & 27.0 & & & & & & & & & & & \\
\hline $8: 00$ & 0.59 & 3.3 & 18.5 & 16.6 & 2.6 & & & & & & & & & & & \\
\hline $8: 30$ & 0.0 & 3.2 & 17.6 & 15.7 & 2.4 &. & & & & & & & & & & \\
\hline $9: 00$ & 0.0 & 3.5 & 18.5 & 16.6 & 2.6 & & & & & & & & & & & \\
\hline $6: 00$ & $\ldots \ldots .$. & $1,180.0$ & $\ldots$ & 944.0 & $\ldots$ & & & & & & & & & & & \\
\hline ......... & 259.0 & 204.0 & 196.0 & 236.0 & 236.0 & & & & & & & & & & & \\
\hline $6: 30$ & 220.0 & 157.0 & 188.0 & 306.0 & 220.0 & & & & & & & & & & & \\
\hline 7:00 & 140.0 & 88.9 & 129.0 & 173.0 & 133.0 & 2 & 0 & 2 & 0 & 2 & 6 & 0 & 3 & 4 & 5 & 24 \\
\hline $7: 30$ & 37.9 & 25.0 & 50.0 & 59.2 & 29.6 & & & & & & & & & & & \\
\hline 8:00 & 0.49 & 3.2 & 18.5 & 15.7 & 2.5 & & & & & & & & & & & \\
\hline $8: 30$ & 0.01 & 3.3 & 19.4 & 17.6 & 2.2 & & & & & & & & & & & \\
\hline 9:00 & 0.0 & 3.6 & 20.4 & 18.5 & 2.5 & & & & & & & & & & & \\
\hline 6:00 & $\therefore . . . . . . . .$. & …1..... & ...……...... & 787.0 & & & & & & & & & & & & \\
\hline & 259.0 & 220.0 & 212.0 & 252.0 & 236.0 & & & & & & & & & & & \\
\hline $6: 30$ & 243.0 & 149.0 & 173.0 & 315.0 & 260.0 & & & & & & & & & & & \\
\hline 7:00 & 140.0 & 101.0 & 120.0 & 181.0 & 141.0 & 2 & $\ldots$. & 1 & 0 & 2 & 4 & 0 & 1 & 8 & 6 & 24 \\
\hline $7: 30$ & 37.9 & 24.0 & 42.6 & 50.9 & 27.8 & & & & & & & & & & & \\
\hline 8:00 & 0.48 & 3.2 & 18.5 & 14.8 & 2.5 & & & & & & & & & & & \\
\hline $8: 30$ & 0.01 & 3.3 & 20.4 & 16.7 & 2.2 & & & & & & & & & & & \\
\hline $9: 00$ & 0.0 & 3.5 & 21.3 & 17.6 & 2.4 & & & & & & & & & & & \\
\hline
\end{tabular}




\section{OBSERVATIONS ON EGG-LAYING HABITS}

An artificial light intensity sufficient to deter the moths from egglaying had been hoped for but this was achieved only to a limited extent. With the trees flooded with light every evening for the entire season it was possible to make many interesting supplementary observations relative to the habits of the codling moth, such as actual egg deposition, mating, flight, etc. These supplementary observations are recorded in a paper by Borden. ${ }^{5}$

A few of these observations are, however, pertinent to this report. Thus the records show that the flight of the moths may extend over a period of approximately 2 hours when weather conditions are favorable, and that the maximum number in flight is usually to be found from about 20 minutes before sunset to about 20 minutes after. The deposition of eggs took place mainly during this sunset period at temperatures ranging from $60^{\circ}$ to $69^{\circ} \mathrm{F}$, and when there is almost no movement of the air. Actual egg deposition was observed, and light measurements and other weather observations were made at the time; among these observations are those given in table 2 .

TABLE 2

Codling Motil Egg Depositions Observed Under Known Light, Temperature, AND HuMidity Conditions

\begin{tabular}{|c|c|c|c|c|c|}
\hline \multirow{2}{*}{ Date } & \multicolumn{4}{|c|}{ Conditions when egg was laid } & \multirow{2}{*}{$\begin{array}{l}\text { Time of } \\
\text { sunset }\end{array}$} \\
\hline & Time & Temperature & $\begin{array}{c}\text { Light } \\
\text { intensity }\end{array}$ & Humidity & \\
\hline April 28 $\quad 1929$ & $\begin{array}{l}P . M . \\
5: 45\end{array}$ & ${ }^{\circ} \mathrm{F}$ & $\begin{array}{l}\text { foot-candles } \\
1.298 .0\end{array}$ & $\begin{array}{l}\text { per cent } \\
94\end{array}$ & $\begin{array}{l}\text { P.M. } \\
6: 51\end{array}$ \\
\hline May 2 & $7: 45$ & 67 & 12.0 & 71 & $6: 55$ \\
\hline 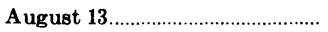 & $7: 45$ & 65 & 17.0 & 70 & $7: 01$ \\
\hline August 18 & $7: 07$ & 65 & 10.0 & 72 & $6: 52$ \\
\hline August 18 & $7: 15$ & 64 & 5.8 & 75 & $6: 52$ \\
\hline August 22 & $6: 42$ & 69 & 11.0 & 68 & $6: 46$ \\
\hline A ugust 25. & $6: 18$ & 65 & 40.2 & 75 & $6: 40$ \\
\hline September 10 & $7: 15$ & 64 & 3.3 & 72 & $6: 18$ \\
\hline
\end{tabular}

That the codling moth may lay its eggs even under very high light intensities is borne out by the April 28 observation, when an egg was laid during a light intensity of 1,298 foot-candles. Moths were first observed in the orchard April 24.

5 Borden, A. D. Some field observations on codling moth behavior. Jour. Econ. Ent. 24 (6) :1137-1145. 1929. 
It is a well-known fact that varieties of apples show a variation in susceptibility to codling-moth attack. This is borne out by the observations recorded in table 3 ; the worminess in the unsprayed, nonilluminated trees of the Ben Davis variety, for example, was 90.9 per cent, whereas in those of the Yellow Newtown variety it was 55.9 per cent.

TABLE 3

Varietal Susceptibility of Apples to Codling-Moth Attack Under ILluminated and Nonilluminated Conditions

\begin{tabular}{|c|c|c|c|c|c|c|c|c|}
\hline \multirow{3}{*}{ Variety } & \multicolumn{6}{|c|}{ Not sprayed } & \multirow{2}{*}{\multicolumn{2}{|c|}{$\frac{\text { Sprayed }}{\begin{array}{c}\text { Not } \\
\text { illuminated }\end{array}}$}} \\
\hline & \multicolumn{2}{|c|}{$\underset{\text { illuminated }}{\text { Fully }}$} & \multicolumn{2}{|c|}{$\begin{array}{c}\text { Partially } \\
\text { illuminated }\end{array}$} & \multicolumn{2}{|c|}{$\begin{array}{c}\text { Not } \\
\text { illuminated }\end{array}$} & & \\
\hline & $\begin{array}{l}\text { Per cent } \\
\text { wormy }\end{array}$ & $\begin{array}{l}\text { Tree } \\
\text { Nos. }\end{array}$ & $\begin{array}{l}\text { Per cent } \\
\text { wormy }\end{array}$ & $\begin{array}{l}\text { Tree } \\
\text { Nos. }\end{array}$ & $\begin{array}{l}\text { Per cent } \\
\text { wormy }\end{array}$ & $\begin{array}{l}\text { Tree } \\
\text { Nos. }\end{array}$ & $\begin{array}{l}\text { Per cent } \\
\text { wormy }\end{array}$ & $\begin{array}{l}\text { Tree } \\
\text { Nos. }\end{array}$ \\
\hline Ben Davis.................. & 80.9 & $2,7,9$ & 93.6 & $1,5,20$ & 90.9 & 23 & 5.4 & 57,58 \\
\hline Yellow Newtown.. & 47.2 & 4 & 59.5 & 21,47 & 55.9 & 25 & 9.1 & $\begin{array}{c}44,46,48 \\
49,56\end{array}$ \\
\hline Skinner Pippin ...... & 44.1 & $8,13,14$ & 60.0 & $\begin{array}{c}6,11,30 \\
40\end{array}$ & 89.1 & $\begin{array}{c}31,32,33 \\
34,35\end{array}$ & 17.0 & 41,43 \\
\hline 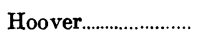 & 35.3 & 3 & 56.2 & 16,18 & 67.9 & 24 & 3.8 & 55 \\
\hline Baldwin & $\ldots \ldots \ldots \ldots$ & ................. & 58.3 & $10,15,17$ & .......... & $\ldots \ldots \ldots . . .$. & 4.2 & $50,51,54$ \\
\hline
\end{tabular}

The data shown in table 3 also support the assumption that artificial illumination as a deterrent had much the same effect on the codling moth with each of the several varieties of apples. 


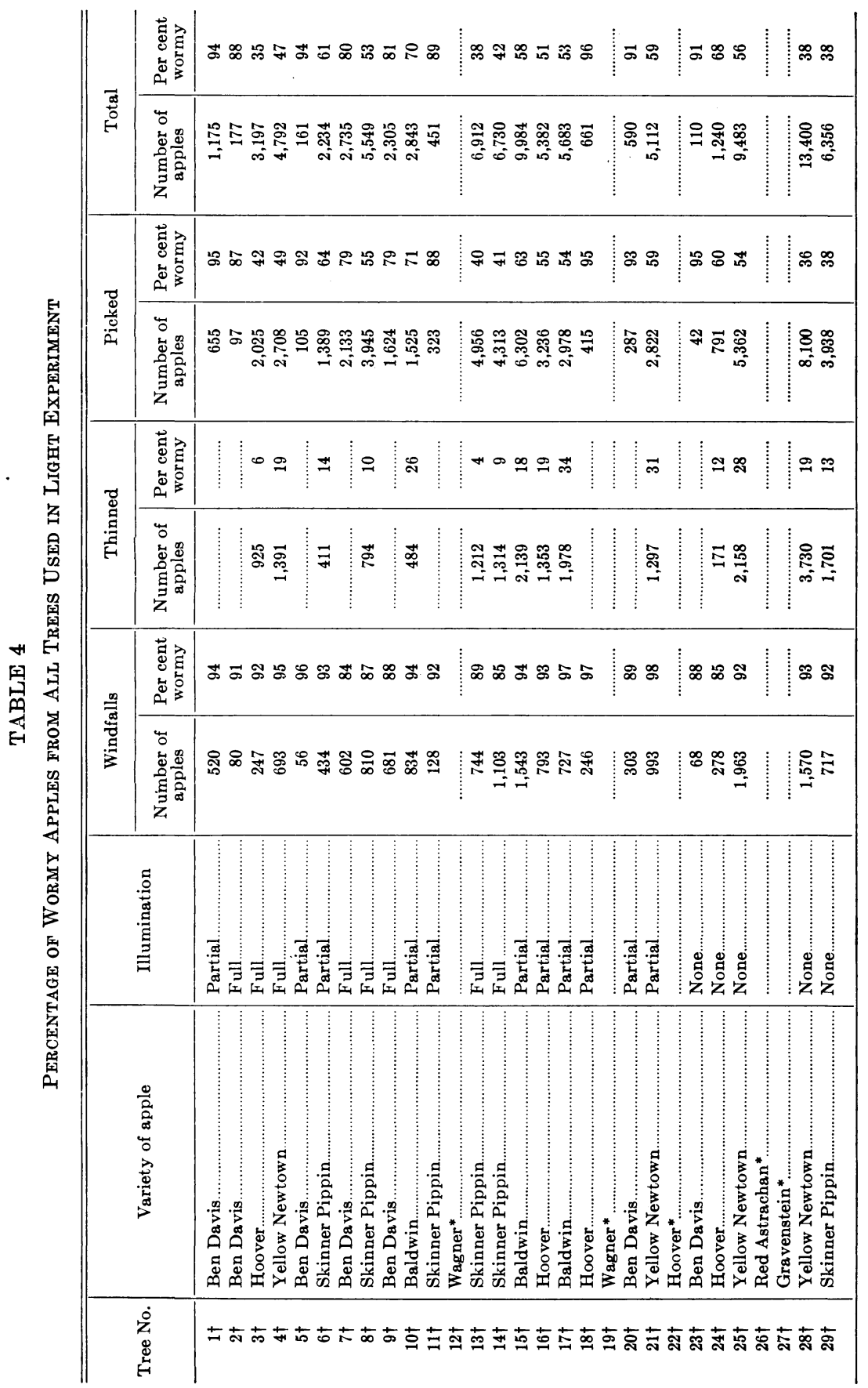




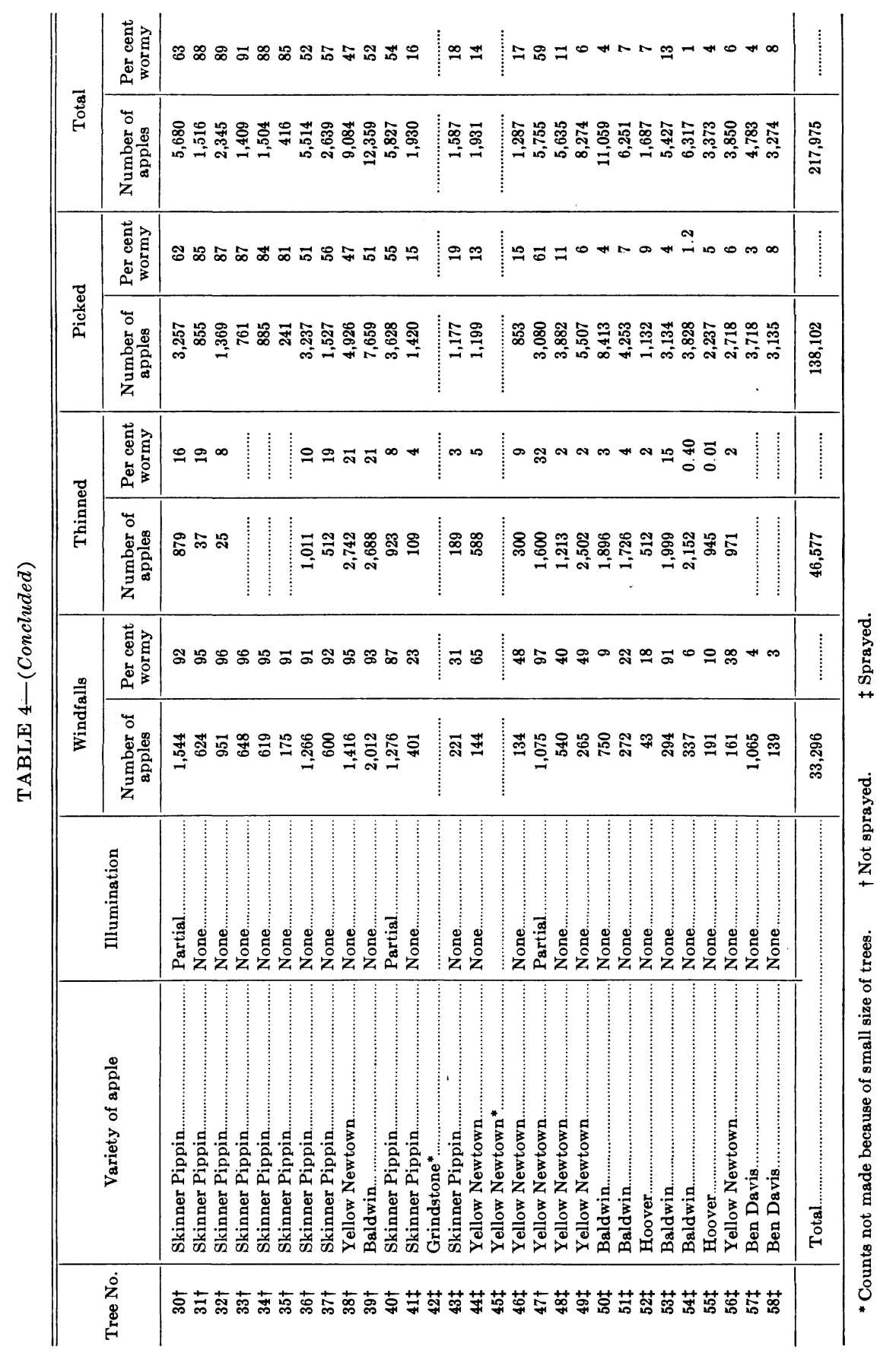




\section{RELATION BETWEEN PERCENTAGE OF WORMINESS AND INTENSITY OF LIGHT}

Table 4 shows the percentage of worminess in all apples from all trees included in this experiment. Segregating the trees according to position in relation to lights, the percentages given in table 5 may be obtained. (See figure 1 for location of trees in the orchard.)

\section{TABLE 5}

Trees Grouped According to Position in Relation to Light, Showing Percentages of Worminess

\begin{tabular}{|c|c|c|c|c|}
\hline Spraying & Illumination & $\begin{array}{l}\text { Number } \\
\text { of trees }\end{array}$ & Tree Nos. & Worminess \\
\hline Unsprayed...... & Total & 8 & $2,3,4,7,8,9,13,14$ & $\begin{array}{l}\text { per cent } \\
49.7\end{array}$ \\
\hline Unsprayed...... & Dimly (closely bordering lighted area) & 14 & $\begin{array}{c}1,5,6,10,11,15,16,17 \\
18,20,21,30,40,47\end{array}$ & 60.2 \\
\hline Unpsrayed...... & Nonilluminated... & 8 & $23,24,25,31,32,33,34,35$ & 71.3 \\
\hline Sprayed *........... & Nonilluminated & 15 & $\begin{array}{l}41,43,44,46,48,49,50 \\
\quad 51,52,53,54,55,56,57 \\
58\end{array}$ & 7.4 \\
\hline
\end{tabular}

* The trees received a calyx spray of 3 pounds acid lead arsenate plus 8 pounds of sulfur to make 100 gallons, and two cover sprays of 3 pounds acid lead arsenate plus 6 pounds of sulfur to make 100 gallons.

Out of the total of 58 trees included in the experiment 45 are accounted for in the percentages given in the table. The following are thrown out of consideration for various reasons : Nos. 12, 19, 22, and 45 because of small size; No. 26, a Red Astrachan, No. 27, a Gravenstein, and No. 42, a Grindstone, which are represented in one group only; also Nos. 28, 29, 36, 37, 38, and 39, all unsprayed and not illuminated, which were located in a distinct swale and hence not ecologically comparable with any other part of the general plot under observation. The percentage of worminess of these thirteen trees was 45.6 per cent.

The highest average artificial light intensity maintained night after night throughout the season at any of the stations was at station No. 6 , which was about 3 feet distant from the overhead source of light and averaged about 20 foot-candles. The station was about 9 feet above the ground and within 6 to 7 feet below the tops of the adjacent trees in a location favorable for codling-moth activity. In spite of this intensity trees 8 and 13, the two most affected by it, showed 53.4 per cent and 38 per cent worminess respectively, or an average of 45.2 per cent, which is close to the average of the illuminated group (49.7 per cent). Trees 
52 and 53 were adjacent to the light area but were sprayed, giving a percentage of worminess of 11.6.

Using the same variety of apple (viz. Skinner Pippin) and proceeding from a point of high artificial illumination, the following percentages of worminess are of interest; trees Nos. 8, 13, and 14 (all illumi-

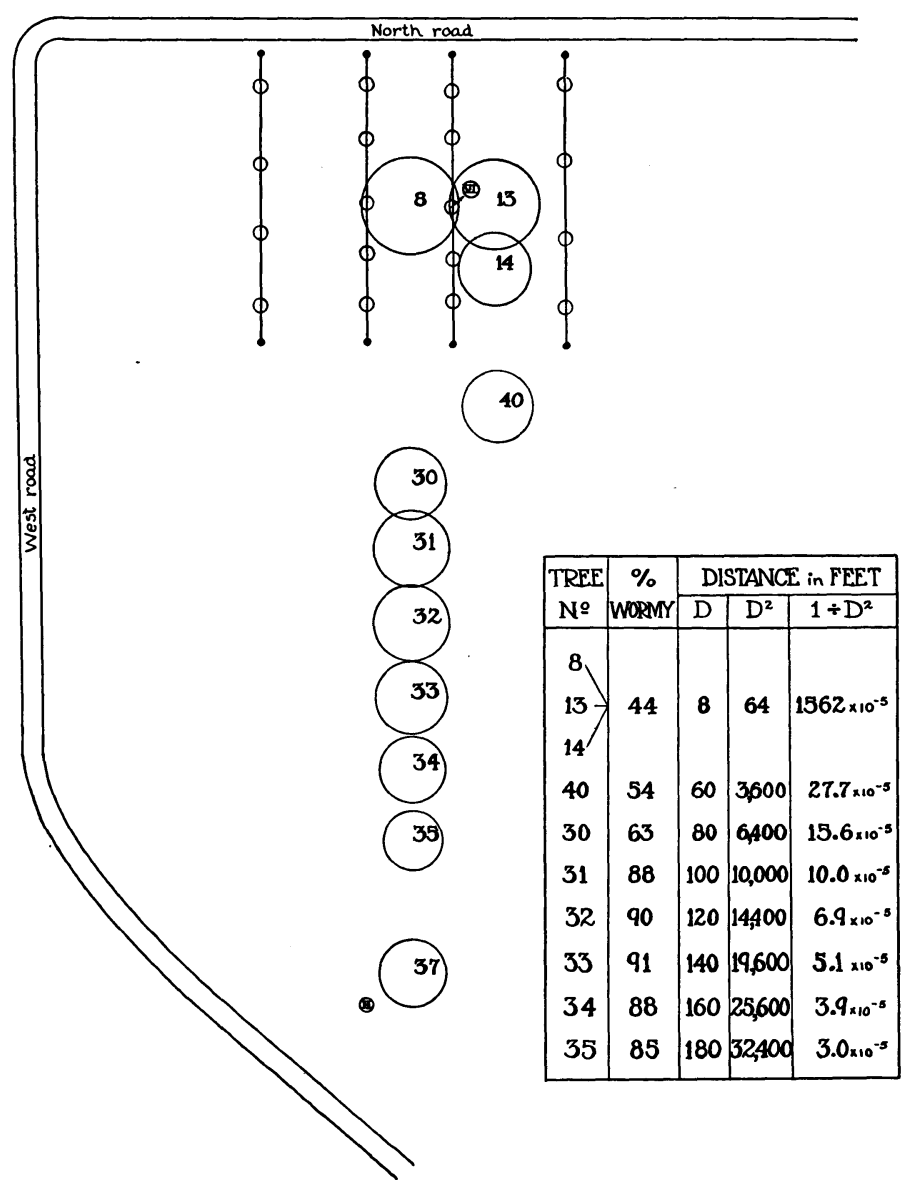

Fig. 3. Location of Skinner Pippin trees in test plot.

nated) showed 44.1 per cent worminess; Nos. 40 and 30, both in dim light, showed 54.7 and 63.0 per cent respectively; thence away from the light, tree No. 31 showed 88.2 per cent; No. $32,89.8$ per cent; No. 33 , 90.9 per cent; No. $34,88.1$ per cent; No. $35,85.3$ per cent. All other factors being equal, one may conclude that differences in light intensity are responsible for this variation in worminess. (See fig. 4.) The aver- 
age percentage of worminess of unsprayed trees not subjected to artificial light and in locations far removed from the test plot was estimated at between 85 and 90 per cent, which corresponds very closely to the percentage of worminess for the trees farthest from the source of light, namely Nos. $31,32,33,34$, and 35 , which show 89.1 per cent worminess.

The curve (fig. 4) showing the percentage of worminess for Skinner Pippins alone is the result of plotting worminess against the reciprocal of the square of the distance from the center of the lighted area. The average distance of the illuminated trees (Nos. 8, 13, and 14) from the

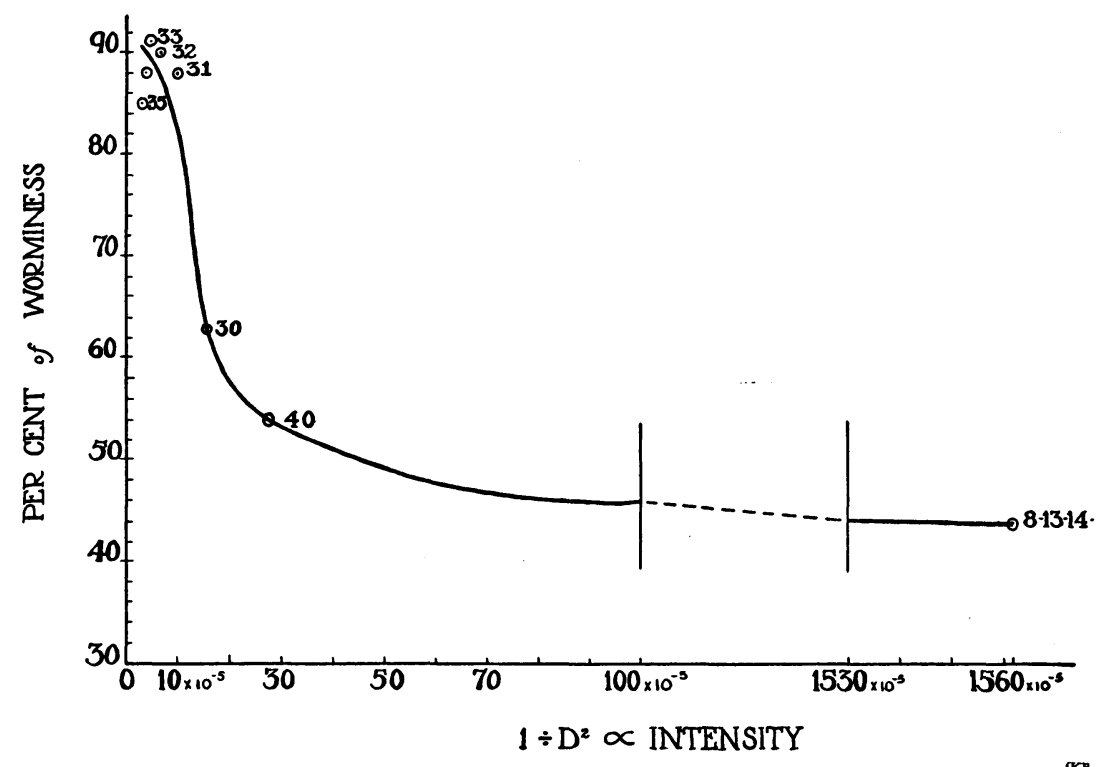

Fig. 4. Relation of the percentage of worminess for Skinner Pippin apples and distance from the source of artificial light. The numbers on the curve represent tree numbers. The curve is the result of plotting worminess against the reciprocal of the square of the distance from the center of the lighted area.

several sources of light in the test plot was estimated at 8 feet, and the other distances are taken from the center of this lighted area. The location of the trees is shown in figure 3 .

The intensity of the light is inversely proportional to the square of the distance from the source of light, and figure 4 shows the curve obtained when worminess is plotted against the term $1 / \mathrm{D}^{2}$, which is closely proportional to the light intensity at every point. This method of measurement is used because of the lack of light stations at the locations of the several trees used for worminess counts. The light-measur- 
ing surfaces were held in a horizontal position, therefore such measurements as were actually made did not represent the horizontal variations.

It may be seen that over a very wide range of light intensity as indicated by values of $1 / \mathrm{D}^{2}$ from $30 \times 10^{-5}$ to $1,560 \times 10^{-5}$ the percentage of worminess is practically constant, and it is not until the function of $1 / \mathrm{D}^{2}$ falls below $30 \times 10^{-5}$ that worminess increases abruptly. In spite of the fact that the term $1 / \mathrm{D}^{2}$ for a point source of illumination is used as a theoretical basis, the use of the possibly more acceptable term 1/D for a line source does not alter the conclusions, for the curve, while flatter, indicates the same effect of light.

The object of the experiments, of course, was to produce light conditions artificially in the orchard that would deter the female codling moth in the deposition of her eggs, with the assumption that eggs are laid principally when the light intensity is relatively low and when the weather is favorable. That there is an optimum light condition during which codling-moth activity takes place seems to be the case, and in the 1928 experiments the highest percentage of moth-attacked apples occurred in that portion of the orchard where the light intensity by artificial illumination remained for the evening at from 0.3 to 0.4 foot-candles, i.e., the intensity of natural light about 20 minutes after sunset. To increase that intensity materially and maintain it throughout the daily flight period of the moth would seem to be a fairly easy thing to do, but unfortunately the range of nondeterrent intensity is unquestionably much higher, as shown by the more extensive observations during the season of 1929 .

An examination of data included in the consolidated table shows that the natural light intensity (station No. 2) for the period of maximum egg deposition ranges from between 72 and 90 foot-candles 20 minutes before sunset, to between 0.3 and 0.5 foot-candles 20 minutes after sunset, indicating a general range of favorable light intensity of from 0.3 foot-candles to 90 foot-candles during which the codling moth will deposit eggs freely. At sunset there is a natural light intensity averaging 30 foot-candles and ranging from 27 to 52 .

Contrasting station No. 2, located outside the artificially illuminated plot, with station No. 6 inside the lighted area, the readings taken at the latter, 20 minutes before sunset show a range of from 92 to 112 footcandles, and for 20 minutes after, the intensity is from about 11 to 16 foot-candles. At sunset this station shows an average light intensity of 51 foot-candles, ranging from 47 to 54 . The variation in light intensity at station No. 2 as compared with station No. 6 is explained by the 
fact that the former (No. 2) was situated in a distinct swale, as already explained, so that the sunset hour for that station was advanced.

In spite of the fact that the light intensity in the test plot was increased during the second season, the relative reduction in the percentage of worminess was not greatly altered in view of the fact that there was a very much increased percentage of worminess in general. There was a 31 per cent reduction in worminess in the light area for $1928^{6}$ (illuminated 14.5 per cent wormy ; nonilluminated 21 per cent), and a reduction of 30 per cent for 1929 (illuminated 49.7 per cent wormy; and nonilluminated 71.3 per cent). Any efficiency that increased light intensity might have had in the control of the codling moth under normal conditions would no doubt have suffered during a year of unusual moth abundance such as 1929 ; i.e., 71.3 per cent worminess as compared with 21 per cent in 1928. That 1929 was an unusually heavy codling-moth season is shown by the bait-pan catches. The total number of moths taken from April 30 to July 1, 1928, was 912 , while with a similar number of pans similarly located the total number of moths taken for the same period during 1929 was 1,845 . The total number of moths taken for the entire season April 26 to September 27 was 2,621 . It is of interest to know that the average number of moths taken per tree was larger in the area away from the light, viz., inside the artificially lighted area the average per tree was 244 (pans Nos. 1 and 2 ), and outside it was 286 per tree (pans Nos. 4, 5, 6, 7, 8, 9, 10).

A field test such as this reveals many questions which can be satisfactorily answered only by further testing in the laboratory. Since the codling moth responds positively to light under laboratory conditions, there remains to be determined the exact range of favorable intensity, together with a more exact determination of the factors which inhibit flight and oviposition. It should be pointed out that since normal maximum egg-laying activity coincides with the rapid decrease of intensity, and inhibition under the conditions of this test appears to be correlated with the maintenance of a constant intensity, i.e., artificial light, the possibility of a change of intensity as in nature as a stimulus to flight and oviposition might be suggested. Since there is some evidence of an occasional sunrise flight this question is further emphasized. Sunrise flights may be rare only because of adverse temperature conditions at that time.

There are also many questions relating to the quality of the light, particularly to the intensity of a specific region of the spectrum. The

6 Herms, W. B. A field test of the effect of artificial light on the behavior of the codling moth, Carpocapsa pomonella (Linn.). Jour. Econ. Ent. 22(1):78-88. 1929. 
time of day when flights occur emphasizes the importance of this matter. Laboratory tests concerning intensity, quality, and constancy of light are in progress, and will be the subject of a later paper.

It is freely conceded that the real test of the efficacy of light in combating the codling moth would come if an entire large area were to be illuminated. That moths prevented from entering the area under effective illumination, as involved in the test here reported, might go elsewhere to more attractive darker areas to deposit their eggs is quite probable. Likewise it is unlikely that moths which succeeded in entering the lighted area in spite of the repellent effects of the light would be deterred from laying their eggs. The reported reduction in worminess is believed to be because there were fewer moths in the illuminated area.

\section{CONCLUSIONS}

1. The total number of apples (from 51 trees) examined for worminess was 217,975 , including thinnings and windfalls. Worminess in apples among varieties that were represented in each group, namely Yellow Newtown, Skinner Pippin, Hoover, and Ben Davis, from the unsprayed, wholly illuminated trees (eight) was 49.7 per cent, while the unsprayed check plot (not artificially illuminated) of eight trees showed 71.3 per cent worminess. The nonilluminated sprayed trees (fifteen) showed 7.4 per cent worminess. In spite of the fact that a higher artificial-light intensity had been used during the second season's work, the relative reduction in worminess for the entire test plot under illuminated and nonilluminated conditions was not greatly changed, i.e., the first season it showed a reduction of 31 per cent (illuminated 14,5 per cent and nonilluminated 21.0 per cent) while the second season showed a reduction of 30 per cent (illuminated 49.7 per cent and nonilluminated 71.3 per cent).

2. Using a single variety, namely Skinner Pippin, the conclusion is reached on the evidence at hand and under the conditions of this test that the percentage of worminess of apples in the more highly illuminated area is much less than the average for the several varieties combined, i.e., there is an apparent reduction of more than 50 per cent (illuminated 44.1 per cent; nonilluminated 89.1 per cent).

3. Since the codling moth deposits eggs rather freely within a light intensity range of from 0.3 to 90.0 foot-candles (station No. 2) with maximum activity between 25 and 52 foot-candles, and in view of the fact that an artificial-light intensity was maintained (station No. 6) ranging from 11 to 112 foot-candles at best, it becomes obvious that the 
intensity of artificial light was not sufficiently high to wholly prevent codling moths from entering this area and depositing eggs. There was nevertheless a substantial decrease in moth attack as noted above.

4. It is evident that the effectiveness of artificial-light intensity in deterring moths remains fairly constant over a wide range of intensity, i.e., $30 \times 10^{-5}$ to $1,560 \times 10^{-5}$, when measured by values of $1 / \mathrm{D}^{2}$, as shown by the curve of worminess, and that it is not until the function of $1 / \mathrm{D}^{2}$ falls below $30 \times 10^{-5}$ that worminess increases abruptly.

\section{ACKNOWLEDGMENTS}

As in the first test, so in this, the second, the author is particularly indebted to Mr. A. Halberg, owner of the orchard, for permission to use his trees for this investigation, and for the many courtesies which he extended throughout these tests. The writer is also greatly indebted to Mr. A. D. Borden, Assistant Entomologist, for his generous assistance in the field and to Dr. W. M. Hoskins for helpful criticism and advice in the study of the accumulated data. Particular mention should be made of the able assistance rendered by Mr. J. K. Ellsworth, Technical Assistant, who was stationed at the orchard throughout the period of the test and who also prepared the tables and drawings under the supervision of the author. Professor Ben D. Moses, Division of Agricultural Engineering and Director Secretary of the California Committee on the Relation of Electricity to Agriculture, has given most cordial support at all times.

The author is particularly indebted to the following members of the faculty who have read the manuscript and have contributed many helpful criticisms : Dr. H. B. Walker, Professor of Agricultural Engineering, Dr. S. C. Brooks, Professor of Zoology, and Dr. S. F. Cook, Associate Professor of Physiology. 